Doi: HTTPS://DOI.ORG/10.23910/IJBSM/2017.8.5.1841

\title{
Soil hydro-physical Environment as Influenced by Different Biochar Amendments
}

\author{
Shaon Kumar Das ${ }^{1,2^{*}}$ and Goutam Kumar Ghosh ${ }^{2}$ \\ ${ }^{1}$ ICAR Research Complex for NEH Region, Sikkim Centre, Tadong, Gangtok (737 102), India \\ ${ }^{2}$ Dept. of Soil Science \& Agricultural Chemistry, Palli-Siksha Bhavana, Visva-Bharati, Sriniketan, West Bengal (731 236), India
}

\section{Corresponding Author}

Shaon Kumar Das

e-mail: shaon.iari@gmail.com

\author{
Article History \\ Article ID: AR1841 \\ Received in $2^{\text {nd }}$ September, 2017 \\ Received in revised form $25^{\text {th }}$ September, 2017 \\ Accepted in final form $5^{\text {th }}$ October, 2017
}

\begin{abstract}
Biochar acts as a soil conditioner, improving soil physical properties, nutrient use efficiency and thereby increasing plant growth. An experiment was conducted at ICAR-National Organic Farming Research Institute during the year 2016-17 in order to study the effect of different levels of biochar obtained from different biomass on selected soil hydro-physical properties. In this study, a sandy loam soil was amended with four different types of biochar (maize, Lantana camara, pine needle and black gram) at four different rates ( 0 , 5.0, 7.5 and $10.0 \mathrm{t} \mathrm{ha}^{-1}$ ). The biochar were characterized for their physico-chemical properties. After biochar application selected soil hydro-physical properties were analyzed for bulk density, porosity, aggregate stability, mean weight diameter, hydraulic conductivity and water holding capacity. Maize biochar was showing best result for improving all the selected the soil physical properties compared to other type. With increasing rate of application of biochar soil physical properties also changed significantly. The results showed that bulk density decreased from 1.53 to $1.13 \mathrm{~g} \mathrm{~cm}^{-3}$ while porosity increased from 58.38 to 65.67 . Aggregate stability and mean weight diameter increased from 4.13 and 2.51 to 8.29 and 2.83 , respectively. But biochar amendment decreased the soil hydraulic conductivity from 0.41 to 0.16 . Besides water holding capacity also increased from 11.37 to $19.8 \mathrm{~g} \mathrm{~cm}^{-3}$. Finally soil moisture content increased significantly from 19.1 to 25.7 for all the biochar. These results strongly suggest positive improvement of soil hydro-physical properties following addition of biochar amendment in sandy loam soil.
\end{abstract}

Keywords: Biochar, hydro-physical properties, bulk density, hydraulic conductivity

\section{Introduction}

Biochar, an ancient soil conditioner or zero waste, is nothing but a carbon rich charcoal-like substance which is formed by heating the biomass in a limited oxygen condition, in a process known as pyrolysis (Abel et al., 2013). Biochar technology is called a geoengineering solution, as it has potential to actively reduce the atmospheric concentrations of green house gases (Das and Mukherjee, 2014). Intensive cultivation has led to a rapid decline in organic matter and nutrient levels besides affecting soil physical properties. Soil organic carbon is an important index of soil fertility because of its relationship to crop productivity. Declining SOC levels often leads to decreased crop productivity. Thus, maintaining SOC level is essential for agricultural sustainability. Biochar can enhance plant growth by improving soil physical condition i.e., water holding capacity, bulk density, porosity, infiltration (Das, 2016 and Das et al., 2015). Locally available biomass which is not economically important can be used as an important source of biomass for preparation of biochar. For a given rate of biochar application, differences in yield response are probably due to the interactive effect of many variables, and mainly to differences in biochar material, physical and chemical characteristics of the experimental soil land management and pyrolysis process (Dong et al., 2015). Some research has highlighted the ability of biochar to increase or maintain soil $\mathrm{pH}$, as do dolomite or agricultural lime, as a fundamental element in the positive yield responses, especially in acid soils (Barman et al., 2015). To improve the soil physical properties and fertility there is a need to increase the soil organic carbon contents. Biochar is such an amendment which is recalcitrant to decomposition for a long period of time and maintain the soil organic carbon status. Biochar can affect soil aggregation through interactions with soil organic matter, minerals, and microorganisms; however, the surface charge characteristics and their development over time determine the long-term effect on soil aggregation (Lopez-Cano et al., 2016). It has been well proved that increased surface area, porosity, and lower bulk density in mineral soil with biochar can alter water retention, aggregation and soil erosion.

Incorporation of biochar into soil modifies soil physical properties such as soil structure, bulk density, porosity, texture, and particle size distribution (Khan et al., 2014). 
This affects important soil function such as water holding capacity, aeration and plant growth. Biochar can alleviate soil compaction by decreasing bulk density, which increase porosity and accentuates favourable soil processes. Application of biochar as a soil amendment reduces tensile strength and penetration resistance (Kammann et al., 2015). In addition to improve soil mechanical properties, it also increase water infiltration rate, reduces runoff and decreases erosion. Biochar reduces saturated hydraulic conductivity in coarse textured soil and increases hydraulic conductivity in heavy textured soil by improving macro pores Haefele et al. (2011). Asai et al. (2009) reported improved saturated hydraulic conductivity of a top soil. Novak et al. (2012) reported an increase in water retention of a loamy sand; Brockhoff et al. (2010) reported an increase in water retention but a decrease in saturated hydraulic conductivity for sand based root zones; Busscher et al. (2010) reported a decrease in soil penetration resistance, but the impact on soil aggregation, infiltration, and waterholding capacity showed mixed results. Novak et al. (2012) reported enhanced moisture storage capacity of Ultisols and Aridisols. Positive effects of biochar have been reported on soil nutrient status and $\mathrm{C}$ sequestration, microbial community or soil biota, and greenhouse gas (GHG) emissions which are related to chemical and biological properties of soils. However, there is little published information about effects of biochar on soil hydro-physical properties. Thus, the objectives of this paper are to create some information regarding the effect of different biochar obtained from different biomass on soil hydro-physical properties.

\section{Materials and Methods}

The experiment was conducted during the year 2016-17 at the experimental farm of ICAR-National Organic Farming Research Institute (formerly ICAR RC for NEH Region, Sikkim Centre) located in the Indian Himalayan region at Tadong $\left(27^{\circ} 20^{\prime} \mathrm{N}\right.$ latitude and $88^{\circ} 37^{\prime} \mathrm{E}$ longitude with $1350 \mathrm{~m}$ amsl), in the state of Sikkim, India. Soil samples used for this experiment (Inceptisol soil) were collected at a depth of 0-15 cm (plough layer) with no history of biochar application. Samples were collected in polythene bags, then dried in shade, ground, sieved through a $2 \mathrm{~mm}$ sieve and stored at room temperature $\left(30 \pm 1^{\circ} \mathrm{C}\right)$. Different physico-chemical properties of soil were analysed with standard method (Jackson, 1973). Organic carbon measured by using the Walkley and Black method (1965), clay, sand and silt measured by employing the Bouyoucos hygrometer (Bouyoucos and Cook, 1967). Soil pH $\left(1: 2.5 \mathrm{H}_{2} \mathrm{O}\right)$, cation exchange capacity [by $1 \mathrm{M} \mathrm{NH}_{4} \mathrm{OAc}(\mathrm{pH} 7)$ extraction], Olsen $\mathrm{P}$ (by $0.5 \mathrm{M} \mathrm{NaHCO}_{3}$ extraction), sulfate [by $0.04 \mathrm{M} \mathrm{Ca}\left(\mathrm{H}_{2} \mathrm{PO}_{4}\right)_{2}$ extraction], were measured according to Black (1965). Acid oxalate-extractable Fe and aluminum (Al) were determined for the initial soil samples by the standard methods of Blakemore et al. (1987). The physico-chemical properties of the soil are presented in Table 1.

Four different types of biochar were prepared from maize
Table 1: Textural and physico-chemical properties of the experimental soil

\begin{tabular}{|c|c|}
\hline Physico-chemical properties & Value \\
\hline $\mathrm{pH}$ & 5.1 \\
\hline Texture & Sandy loam \\
\hline Sand, $0.02-2$ mm (\%) & 45.1 \\
\hline Silt, 0.002-0.2 mm (\%) & 27.3 \\
\hline Clay, <0.002 mm (\%) & 27.6 \\
\hline Organic carbon (\%) & 1.08 \\
\hline CEC (meq $\left.100 \mathrm{~g}^{-1}\right)$ & 4.28 \\
\hline Bulk density $\left(\mathrm{g} \mathrm{cm}^{-3}\right)$ & 1.53 \\
\hline Aggregate stability (\%) & 4.13 \\
\hline Mean weight diameter (mm) & 2.51 \\
\hline Saturated hydraulic conductivity $\left(\mathrm{cm} \mathrm{s}^{-1}\right)$ & 0.41 \\
\hline Particle density $\left(\mathrm{g} \mathrm{cm}^{-3}\right)$ & 2.40 \\
\hline Total porosity (\%) & 54.38 \\
\hline Water in air dry soil (\%) & $1.1 \%$ \\
\hline Volume expansion (\%) & $5.08 \%$ \\
\hline Water holding capacity $\left(\mathrm{g} \mathrm{cm}^{-3}\right)$ & 11.3 \\
\hline Specific gravity & 2.39 \\
\hline Olsen $\mathrm{P}\left(\mathrm{mg} \mathrm{kg}^{-1}\right)$ & 5.24 \\
\hline $\mathrm{SO}_{4}\left(\mathrm{mg} \mathrm{kg}^{-1}\right)$ & 17.24 \\
\hline Acid oxalate Al\% & $0.87 \%$ \\
\hline Acid oxalate $\mathrm{Fe} \%$ & $0.64 \%$ \\
\hline
\end{tabular}

stalk, Lantana camara biomass, pine needle and black gram stover biomass using the slow pyrolysis method at $450^{\circ} \mathrm{C}$ for $1.2 \mathrm{~h}$. The biochar were applied at four different doses viz., $0,5.0,7.5$ and $10.0 \mathrm{t} \mathrm{ha}^{-1}$. The properties of the biochar used for this study are shown in Table 2. In laboratory, biochar was passed through a $2 \mathrm{~mm}$ sieve to correspond with USDA textural limit for soil. Different types of procedures were used to determine the bulk density, soil porosity, aggregate stability, mean weight diameter, water holding capacity, hydraulic conductivity and soil moisture content of the soil under study. Different types of biochar were mixed with the sandy loam soil with various levels viz., 0, 5.0, 7.5 and $10.0 \mathrm{t}$ ha $^{-1}$. Each air-dried sample was packed in a standard brass core, with successive amounts of about $5 \mathrm{~cm}^{3}$ of material added gradually with frequent stirring to avoid layering. Cylinders were tapped smoothly until they were completely full (Blake and Hartage, 1986). All the samples were packed in triplicate. Thus for all the properties under this experiment, the values were obtained from the average of triplicates. The experiment was laid out in a Completely Randomized Block Design (CRBD). For the determination of bulk density, to obtain the oven-dry mass core samples were placed in the oven at $105^{\circ} \mathrm{C}$ for $24 \mathrm{~h}$. The volume of the samples was calculated from the 
Table 2: Chemical properties of biochar derived from different biomass

\begin{tabular}{|c|c|c|c|c|}
\hline Parameters & $\begin{array}{l}\text { Maize } \\
\text { stock } \\
\text { biochar }\end{array}$ & $\begin{array}{l}\text { Lantana } \\
\text { camara } \\
\text { biochar }\end{array}$ & $\begin{array}{c}\text { Pine } \\
\text { needle } \\
\text { biochar }\end{array}$ & $\begin{array}{c}\text { Black gram } \\
\text { stover } \\
\text { biochar }\end{array}$ \\
\hline $\begin{array}{l}\text { Volatile organic } \\
\text { content (\%) }\end{array}$ & 19.6 & 15.7 & 13.6 & 17.6 \\
\hline $\mathrm{pH}$ & 9.38 & 9.21 & 9.03 & 8.91 \\
\hline $\begin{array}{l}\text { Moisture } \\
\text { content (\%) }\end{array}$ & 12.9 & 10.3 & 8.6 & 9.8 \\
\hline Total N $\left(\mathrm{g} \mathrm{kg}^{-1}\right)$ & 11.3 & 7.2 & 6.8 & 12.8 \\
\hline Total P $\left(\mathrm{g} \mathrm{kg}^{-1}\right)$ & 1.93 & 1.81 & 1.53 & 1.73 \\
\hline Total C ( $\left.\mathrm{g} \mathrm{kg}^{-1}\right)$ & 715 & 735 & 724 & 703 \\
\hline Ash (\%) & 21.5 & 25.7 & 29.7 & 34.3 \\
\hline $\operatorname{CEC}\left(\mathrm{cmol} \mathrm{kg}^{-1}\right)$ & 37.6 & 29.7 & 24.2 & 18.3 \\
\hline Alkalinity & 135.2 & 121.3 & 115.9 & 109.3 \\
\hline $\mathrm{Ca}\left(\mathrm{g} \mathrm{kg}^{-1}\right)$ & 7.52 & 7.51 & 7.39 & 7.12 \\
\hline $\mathrm{Mg}\left(\mathrm{g} \mathrm{kg}^{-1}\right)$ & 5.36 & 5.16 & 5.02 & 4.97 \\
\hline $\mathrm{K}\left(\mathrm{g} \mathrm{kg}^{-1}\right)$ & 21.8 & 20.1 & 19.8 & 19.1 \\
\hline $\mathrm{Na}\left(\mathrm{g} \mathrm{kg}^{-1}\right)$ & 7.3 & 7.2 & 6.9 & 6.7 \\
\hline $\begin{array}{l}\text { Bulk density (g } \\
\mathrm{ml}^{-1} \text { ) }\end{array}$ & 0.31 & 0.34 & 0.37 & 0.41 \\
\hline $\begin{array}{l}\text { Water holding } \\
\text { capacity }\end{array}$ & 179 & 165 & 157 & 151 \\
\hline $\begin{array}{l}\text { Surface area } \\
\left(\mathrm{m}^{2} \mathrm{~g}^{-1}\right)\end{array}$ & 2.1 & 1.9 & 1.7 & 1.4 \\
\hline $\begin{array}{l}\text { Total pore vol- } \\
\text { ume }\left(\mathrm{ml} \mathrm{g}^{-1}\right)\end{array}$ & 0.95 & 0.92 & 0.91 & 0.87 \\
\hline
\end{tabular}

volume of the core with a Vernier caliper used to measure the height and internal diameter. Hence, the bulk density was determined by calculating the ratio of the oven-dry mass to volume of the sample $\left(\mathrm{g} \mathrm{cm}^{-3}\right)$. Soil textural analysis was determined using the Bouyoucos hydrometer method (Gee and Bauder, 1979). Total porosity was calculated from bulk density using the formualar: $T p=100\left(1-B_{d} / P_{d}\right)$; where $B_{d}=$ bulk density, $\mathrm{P}_{\mathrm{d}}=$ particle density (Obi, 2000). Hydraulic conductivity was determined using a $30.2 \mathrm{~cm}$ length and $4.5 \mathrm{~cm}$ diameter infiltrometer (Zhang, 1997). This method involves measuring cumulative infiltration against time and after then hydraulic conductivity measured through van Genuchten parameters for a given soil type. Mean weight diameter was determined by calculation as described by Kemper and Rosenau (1986). Aggregate stability was determined using the wet sieving method described by Kemper and Rosenau (1986). Moisture content was determined by calculation as outlined by Obi (2000). Water holding capacity was determined as per the procedure of Das and Mukherjee (2012). All the data obtained was statistically analysed using the F-following Gomez and
Gomez. LSD values at $p=0.05$ were used to determine the significance of difference between treatment means.

\section{Results and Discussion}

AEffects of biochar on soil hydro-physical properties depend on several factors viz. biomass type, pyrolytic condition, environmental condition as well as application rate. Four different biochar from maize stalk, Lantana camara, pine needle and black gram stover has been prepared at $450{ }^{\circ} \mathrm{C}$ and characterized for different chemical properties (Table 2). Biochar was applied at four different rate viz. 0, 5.0, 7.5 and $10.0 \mathrm{t} \mathrm{ha}^{-1}$. Effect of different biochar on soil porosity and bulk density on amended soil has been shown in Table 3. The results revealed that soil porosity increased with application of

Table 3: Effect of biochar on soil porosity, bulk density, aggregate stability and MWD on amended soil

\begin{tabular}{|c|c|c|c|c|c|}
\hline $\begin{array}{l}\text { Type of } \\
\text { biochar }\end{array}$ & $\begin{array}{l}\text { Application } \\
\text { rate }\end{array}$ & $\begin{array}{l}\text { Soil } \\
\text { po- } \\
\text { rosity } \\
(\%) \\
\end{array}$ & $\begin{array}{l}\text { Bulk } \\
\text { den- } \\
\text { sity (g } \\
\left.\mathrm{cm}^{-3}\right)\end{array}$ & $\begin{array}{l}\text { Aggre- } \\
\text { gate } \\
\text { stabil- } \\
\text { ity \% } \\
\end{array}$ & $\begin{array}{c}\text { Mean } \\
\text { weight } \\
\text { diameter } \\
(\mathrm{mm})\end{array}$ \\
\hline \multirow{4}{*}{$\begin{array}{l}\text { Maize } \\
\text { stock } \\
\text { biochar }\end{array}$} & 0 t ha $^{-1}$ & 54.38 & 1.53 & 4.13 & 2.51 \\
\hline & $5.0 \mathrm{t} \mathrm{ha}^{-1}$ & 59.27 & 1.34 & 6.39 & 2.67 \\
\hline & 7.5 t ha $^{-1}$ & 62.39 & 1.21 & 7.89 & 2.73 \\
\hline & $10.0 \mathrm{t} \mathrm{ha}^{-1}$ & 65.67 & 1.13 & 8.29 & 2.83 \\
\hline \multirow{4}{*}{$\begin{array}{l}\text { Lantana } \\
\text { camara } \\
\text { biochar }\end{array}$} & 0 t ha $^{-1}$ & 54.38 & 1.53 & 4.13 & 2.51 \\
\hline & $5.0 \mathrm{t} \mathrm{ha}^{-1}$ & 58.39 & 1.39 & 6.03 & 2.64 \\
\hline & $7.5 \mathrm{t} \mathrm{ha}^{-1}$ & 57.51 & 1.28 & 7.69 & 2.71 \\
\hline & $10.0 \mathrm{t} \mathrm{ha}^{-1}$ & 64.42 & 1.19 & 8.03 & 2.76 \\
\hline \multirow{4}{*}{$\begin{array}{l}\text { Black } \\
\text { gram } \\
\text { stover } \\
\text { biochar }\end{array}$} & 0 t ha $^{-1}$ & 54.38 & 1.53 & 4.13 & 2.51 \\
\hline & 5.0 tha $^{-1}$ & 57.69 & 1.41 & 5.86 & 2.66 \\
\hline & $7.5 \mathrm{t} \mathrm{ha}^{-1}$ & 60.27 & 1.31 & 6.97 & 2.69 \\
\hline & $10.0 \mathrm{t} \mathrm{ha}^{-1}$ & 63.43 & 1.24 & 7.64 & 2.73 \\
\hline \multirow{4}{*}{$\begin{array}{l}\text { Pine } \\
\text { needle } \\
\text { biochar }\end{array}$} & 0 t ha $^{-1}$ & 54.38 & 1.53 & 4.13 & 2.51 \\
\hline & $5.0 \mathrm{t} \mathrm{ha}^{-1}$ & 56.49 & 1.43 & 5.71 & 2.59 \\
\hline & 7.5 t ha-1 $^{-1}$ & 59.37 & 1.35 & 6.62 & 2.62 \\
\hline & $10.0 \mathrm{t} \mathrm{ha}^{-1}$ & 62.35 & 1.29 & 7.07 & 2.66 \\
\hline \multicolumn{2}{|l|}{ SEm \pm} & 1.41 & 0.01 & 0.31 & 0.06 \\
\hline \multicolumn{2}{|c|}{$\operatorname{LSD}(p=0.05)$} & 4.83 & 0.04 & 0.74 & 0.17 \\
\hline
\end{tabular}

all type of biochar with increase in application rate. The initial porosity of the sandy loam soil was $54.38 \%$ in control (without biochar) and it increased to $65.67 \%$ with application of maize biochar, $64.42 \%$ with Lantana camara biochar, $63.42 \%$ with pine needle biochar and $62.35 \%$ with black gram stover biochar @ $10 \mathrm{t} \mathrm{ha}^{-1}$. Similar results were found by Ouyang and Zhang (2013) in coarse sandy soil. Similarly the initial bulk density of the soil was $1.53 \mathrm{~g} \mathrm{~cm}^{-3}$ in control (without biochar) which decreased to $1.13,1.19,1.24$ and $1.29 \mathrm{~g} \mathrm{~cm}^{-3}$ 
with maize, Lantana camara, pine needle and black gram biochar, respectively, @ 10 t ha $^{-1}$ (Table 3). These results were similar to the experiment conducted by Khan et al., 2016. Haefele et al. (2011) also reported a decrease in topsoil bulk density for an irrigated lowland site and rainfed upland, but no effect on a rainfed lowland site. On the other hand initial soil aggregate stability was $4.13 \%$ in control (without biochar). This gradually increased with biochar application in the order 8.29, 8.03, 7.64 and 7.07\%, respectively, for maize, Lantana camara, pine needle and black gram @ 10 t ha ${ }^{-1}$. Mean weight diameter also increased from $2.51 \mathrm{~mm}$ (initial) to 2.83, 2.76, 2.73 and $2.66 \mathrm{~mm}$, respectively, for maize, Lantana camara, pine needle and black gram @ $10 \mathrm{t} \mathrm{ha}^{-1}$ (Table 3). Such findings have been reported by Lehmann et al., 2011 and Lu et al., 2014. All the above mentioned physical parameter had significantly enhanced by application of biochar and also type of biochar has significant impact on the soil physical property. But the best one was maize biochar. Effect of biochar on water holding capacity, soil moisture content and hydraulic conductivity has been shown in Table 4. Results revealed that

Table 4: Effect of biochar on water holding capacity, soil moisture content and hydraulic conductivity

\begin{tabular}{|c|c|c|c|c|}
\hline $\begin{array}{l}\text { Type of } \\
\text { biochar }\end{array}$ & $\begin{array}{l}\text { Applica- } \\
\text { tion rate }\end{array}$ & $\begin{array}{l}\text { Water } \\
\text { holding } \\
\text { capacity } \\
\left(\mathrm{g} \mathrm{cm}^{-3}\right)\end{array}$ & $\begin{array}{c}\text { Soil } \\
\text { moisture } \\
\text { content } \\
(\%)\end{array}$ & $\begin{array}{l}\text { Hydraulic } \\
\text { conduc- } \\
\text { tivity }(\mathrm{cm} \\
\left.\mathrm{s}^{-1}\right)\end{array}$ \\
\hline \multirow{4}{*}{$\begin{array}{l}\text { Maize } \\
\text { stock } \\
\text { biochar }\end{array}$} & 0 t ha $^{-1}$ & 11.3 & 19.1 & 0.41 \\
\hline & $5.0 \mathrm{t} \mathrm{ha}^{-1}$ & 15.6 & 23.4 & 0.31 \\
\hline & $7.5 \mathrm{t} \mathrm{ha}^{-1}$ & 17.3 & 24.3 & 0.22 \\
\hline & $10.0 \mathrm{t} \mathrm{ha}^{-1}$ & 19.8 & 25.7 & 0.16 \\
\hline \multirow{4}{*}{$\begin{array}{l}\text { Black } \\
\text { gram } \\
\text { stover } \\
\text { biochar }\end{array}$} & 0 t ha- & 11.3 & 19.1 & 0.41 \\
\hline & $5.0 \mathrm{t} \mathrm{ha}^{-1}$ & 14.3 & 22.8 & 0.35 \\
\hline & 7.5 t ha $^{-1}$ & 16.4 & 23.6 & 0.27 \\
\hline & $10.0 \mathrm{t} \mathrm{ha}^{-1}$ & 18.7 & 24.8 & 0.18 \\
\hline \multirow{4}{*}{$\begin{array}{l}\text { Pine } \\
\text { needle } \\
\text { biochar }\end{array}$} & 0 t ha $^{-1}$ & 11.3 & 19.1 & 0.41 \\
\hline & $5.0 \mathrm{t} \mathrm{ha}^{-1}$ & 14.8 & 22.1 & 0.36 \\
\hline & $7.5 \mathrm{t} \mathrm{ha}^{-1}$ & 16.6 & 23.5 & 2.29 \\
\hline & 10.0 t ha $^{-1}$ & 18.1 & 24.5 & 0.19 \\
\hline Lantana & 0 t ha $^{-1}$ & 11.3 & 19.1 & 0.41 \\
\hline \multirow{3}{*}{$\begin{array}{l}\text { camara } \\
\text { biochar }\end{array}$} & $5.0 \mathrm{t} \mathrm{ha}^{-1}$ & 13.1 & 21.7 & 0.34 \\
\hline & 7.5 t ha $^{-1}$ & 15.4 & 23.7 & 0.26 \\
\hline & 10.0 t ha $^{-1}$ & 17.8 & 24.1 & 0.21 \\
\hline \multicolumn{2}{|l|}{ SEm \pm} & 0.31 & 0.22 & 0.02 \\
\hline \multicolumn{2}{|c|}{ LSD $(p=0.05)$} & 0.88 & 0.64 & 0.05 \\
\hline
\end{tabular}

all the type of biochar increased water holding capacity as well as soil moisture content. The data indicated that water holding capacity increased with application of biochar from initial $11.3 \mathrm{~g} \mathrm{~cm}^{-3}$ (without biochar) to $19.8,18.7,17.1$ and $17.8 \mathrm{~g} \mathrm{~cm}^{-3}$ for maize, Lantana camara, pine needle and black gram, respectively, @ 10 t ha $^{-1}$. Similarly soil moisture content also increased from initial $19.1 \%$ (without biochar) to final 25.7, 24.8, 24.5 and $24.1 \%$ for maize, Lantana camara, pine needle and black gram, respectively @ 10 t ha $^{-1}$ (Table ). But hydraulic conductivity decreased from initial value $0.41 \mathrm{~cm}$ $\mathrm{s}^{-1}$ (without biochar) to final value $0.16,0.18,0.19$ and 0.21 $\mathrm{cm} \mathrm{s}^{-1}$, respectively, for maize, Lantana camara, pine needle and black gram @ 10 t ha $^{-1}$ (Table 4). Interestingly, decrease in hydraulic conductivity was more in black gram biochar compared to maize and other biochar. Very similar result was obtained by Sanchez-Garcia et al., 2015; Wiedner et al., 2015.

Bulk density decreased with the rate of biochar amendment. Bulk density is a measure of the relative mass of a solid relative to the bulk volume the solid occupies, including the void spaces. Thus greater is the portion occupied by the pores, the lower is the bulk density of a solid. Lower bulk density indicates an increase in pore space which enhances the potential for soil aeration and increase water holding capacity. However, as reported by Githinji et al. (2011), besides bulk density other physical indicator also important for management of soil quality. In this research experiment porosity increased with increased rate of biochar application which has already documented by Tang et al., 2013. The decrease in hydraulic conductivity was significant as a function of biochar amendment; this was likely due to the hydrophobicity of the organic matter present in biochar amendment Jein and Wang (2013). He indicated a significant decrease in bulk density, increase in porosity and decrease in saturated hydraulic conductivity with biochar application. The increase in total porosity and decrease in bulk density with biochar application might be caused by physical dilution effects (Busscher et al., 2011). They indicated that increasing TOC by biochar amendments addition in soils decrease bulk density significantly. The decrease in bulk density appears to have been the result of alteration of soil aggregate sizes (Vandecasteele et al., 2016). Asai et al. (2009) indicated that biochar incorporation into soil changed the pore-size distribution. This leads to increase in water permeability. The increase in mean weight diameter could be attributed to an increase in oxidized functional groups which generally produced after mineralization of biochar (Herath et al., 2013). These facilitated flocculation of both the soil particles and the biochar (Jien and Wang, 2013). Li et al. (2012) found that soil aggregate sizes and stability could be significantly increased for the sandy loam soil through the addition of biochar to the soil. In sandy soil, it also increases the water holding capacity (Oleszczuk, 2014). The unique property of biochar which makes it as an attractive soil amendment is its highly porous structure. This is responsible for increased water holding capacity and nutrient retention capacity (Prost et al., 2013). The pores in biochar provide suitable habitat for soil microbes by protecting them from predation and drying 
and also provide carbon, energy and mineral nutrient sources (Mukherjee et al., 2016).

\section{Conclusion}

Biochar amendment had a positive impact on the physical properties of soil. All the types of biochar decreased the bulk density of the soil and increased total soil porosity which would leads to enhance plant growth due to sufficient moisture and oxygen in root zone. Moreover, biochar increase aggregate stability and mean weight diameter with decreasing hydraulic conductivity of the soil. Thus different biochar have different impact on soil physical properties. However, longterm researches are needed to facilitate the understanding of effects of biochar on soil hydro-physical properties.

\section{Acknowledgement}

This is a part of Ph.D research work of the first author. The first author is thankful to the Director, ICAR Research Complex for NEH Region, Umiam, Meghalaya for providing financial and research facility during his Ph.D work.

\section{References}

Abel, S., Peters, A., Trinks, S., Schonsky, H., Facklam, M., Wessolek, G., 2013. Impact of biochar and hydrochar addition on water retention and water repellency of sandy soil. Geoderma 202, 183-191.

Asai, H, Samson, B.K., Haefele, S.M., Songyikhangsuthor, K., Homma, K., Kiyono, Y., Inoue, Y., Shiraiwa, T., Horie, T., 2009. Biochar amendment techniques for upland rice production in Northern Laos. Soil physical properties, leaf SPAD and grain yield. Field Crops Research 111, 81-84.

Barman, H., Roy, A., Das, S.K., 2015. Evaluation of plant products and antagonistic microbes against grey blight (Pestalotiopsis theae), a devastating pathogen of tea. African Journal of Microbiology Research 9(18), 1263-1267.

Black, C.A., 1965. Method of Soil Analysis (parts 1 and 2). American Society of Agronomy, Madison, WI.

Blake, G.R., Hartage, K.H., 1986. Bulk Density In: Klute A. (ED). Methods of soil analysis part 1; American Society of Agronomy No. 9 Madison, Wisconsin, 365 - 375.

Blakemore, L.C., Searle, P.L., Daly, B.K., 1987. Methods for Chemical Analysis of Soils New Zealand Soil Bureau Scientific Report.

Bouyoucos, G.J., Cook, R.L., 1967. Measuring the relative humidity of soils at different moisture contents by the gray hydrocal hygrometer. Soil Science 104, 297-305.

Brockhoff, S.R., Christians, N.E., Killorn, R.J., Horton, R., Davis, D.D., 2010. Physical and mineralnutrition properties of sand-based turfgrass root zones amended with biochar. Agronomy Journal 102, 1627-1631.

Busscher, W., Novak, J.M., Ahmedna, M., 2011. Physical effects of organic matter amendment of a southeastern US coastal loamy sand. Soil Science 176, 661- 667.

Das, S.K., 2014. Role of micronutrient in rice cultivation and management strategy in organic agriculture-A reappraisal. Agricultural Sciences 5(09), 765.

Das, S.K., Mukherjee, I., Kumar, A., 2015. Effect of soil type and organic manure on adsorption-desorption of flubendiamide. Environmental monitoring and assessment 187(7), 403.

Das, S.K., Mukherjee, I., 2014. Influence of microbial community on degradation of flubendiamide in two Indian soils. Environmental Monitoring \& Assessment 186, 3213-3219.

Dong, D., Feng, Q., McGrouther, K., Yang, M., Wang, H., Wu, W., 2015. Effects of biochar amendment on rice growth and nitrogen retention in a waterlogged paddy field. Journal of Soils Sediments 15, 153-162.

Gee, G.W., Bauder, J.W., 1979. Particle size analysis by hydrometer: a simplified method for routine textural analysis and a sensitivity test of measured parameters. Soil Science Society of America Journal 43, 1004-1007.

Githinji, L.J.M., Dane, J.H., Walker, R.H., 2011. Physical and hydraulic properties of inorganic amendments and modeling their effects on water movement in sandbased root zones. Irrigation Science 29, 65-77.

Haefele, S., Konboon, Y., Wongboon, W., Amarante, S., Maarifat, A., Pfeiffer, E., Knoblauch, C., 2011. Effects and fate of biochar from rice residues in rice-based systems. Field Crops Research 121, 430-441.

Herath, H., Camps-Arbestain, M., Hedley, M., 2013. Effect of biochar on soil physical properties in two contrasting soils: an Alfisol and an Andisol. Geoderma 209-210, 188-197.

Jackson, M.L., 1973. Soil chemical analysis. New Delhi: Prentice Hall.

Jien, S.H., Wang, C.S., 2013. Effects of biochar on soil properties and erosion potential in a highly weathered soil. Catena 110, 225-233.

Kammann, C.I., Schmidt, H.P., Messerschmidt, N., Linsel, S., Steffens, D., Muller, C., Godlewska, P., Koyro, H.W., Conte, P., Stephen, J., 2015. Plant growth improvement mediated by nitrate capture in co-composted biochar. Scientific Reports 5, 11080.

Kemper, W.D., Rosenau, R.C., 1986. Aggregate and size distribution In: Klute A. (Ed.) Methods of Soil Analysis; Part 1; Physical and Mineralogical Methods $2^{\text {nd }}$ edn. ASA, SSSA, Madison, W.I. USA, 425-442.

Khan, N., Clark, I., Sanchez-Monedero, M.A., Shea, S., Meier, S., Bolan, N., 2014. Maturity indices in co-composting of chicken manure and sawdust with biochar. Bioresource Technology 168, 245-251 (Special Issue on Advance Biological Treatment Technologies for Sustainable Waste Management (ICSWHK2013)).

Khan, N., Clark, I., Sanchez-Monedero, M.A., Shea, S., Meier, S., Qi, F., Kookana, R.S., Bolan, N., 2016. Physical and 
chemical properties of biochars co-composted with biowastes and incubated with a chicken litter compost. Chemosphere 142, 14-23.

Lehmann, J., Rillig, M.C., Thies, J., Masiello, C.A., Hockaday, W.C., Crowley, D., 2011. Biochar effects on soil biota-a review. Soil Biology and Biochemistry 43, 1812-1836.

Li, R., Wang, Q., Zhang, Z., Zhang, G., Li, Z., Wang, L., Zheng, J., 2015. Nutrient transformation during aerobic composting of pig manure with biochar prepared at different temperatures. Environmental Technology 36, 815-826.

Lopez-Cano, I., Roig, A., Cayuela, M.L., Alburquerque, J.A., Sanchez-Monedero, M.A., 2016. Biochar improves N cycling during composting of olive mill wastes and sheep manure. Waste Management 49, 553-559.

Lu, S.G., Sun, F.F., Zong, Y.T., 2014. Effect of rice husk biochar and coal fly ash on some physical properties of expansive clayey soil (Vertisol). Catena 114, 37-44.

Mukherjee, I., Das, S.K., Kumar, A., 2016. Degradation of flubendiamide as affected by elevated $\mathrm{CO}_{2}$, temperature, and carbon mineralization rate in soil. Environmental Science and Pollution Research 23(19), 19931-19939

Novak, J.M., Busscher, W.J., Watts, D.W., Amonette, J., Ippolito, J.A., Lima, I.M., Gaskin, J., Das, K.C., Steiner, C., Ahmedna, M., 2012. Biochars impact on soil moisture storage in an Ultisol and two Aridisols. Soil Science 177, 310-320.

Obi, M.E., 2000. A Compendium of lectures on soil physics, Atlanta Publishers, Nsukka, Nigeria.

Oleszczuk, P., Josko, I., Kusmierz, M., Futa, B., Wielgosz, E., Ligeza, S., Pranagal, J., 2014. Microbiological, biochemical and ecotoxicological evaluation of soils in the area of biochar production in relation to polycyclic aromatic hydrocarbon content. Geoderma 213, 502-511.
Ouyang, L., Zhang, R., 2013. Effects of biochars derived from different feedstocks and pyrolysis temperatures on soil physical and hydraulics properties. Journal of Soils Sediments 13, 1561-1572.

Prost, K., Borchard, N., Siemens, J., Kautz, T., Sequaris, J.M., Moller, A., Amelung, W., 2013. Biochar Affected by Composting with Farmyard Manure. Journal of Environmental Quality 42, 164.

Sanchez-Garcia, M., Alburquerque, J.A., Sanchez-Monedero, M.A., Roig, A., Cayuela, M.L., 2015. Biochar accelerates organic matter degradation and enhances $\mathrm{N}$ mineralization during composting of poultry manure without a relevant impact on gas emissions. Bioresource Technology 192, 272-279.

Tang, J., Zhu, W., Kookana, R., Katayama, A., 2013. Characteristics of biochar and its application in remediation of contaminated soil. Journal of Bioscience and Bioengineering 116, 653-659.

Vandecasteele, B., Willekens, K., Steel, H., D'Hose, T., Waes, C.V., Bert, W., 2016. Feedstock mixture composition as key factor for $c / p$ ratio and phosphorus availability in composts: Role of biodegradation potential, biochar amendment and calcium content. Waste Biomass Valorization 1-15.

Wiedner, K., Fischer, D., Walther, S., Criscuoli, I., Favilli, F., Nelle, O., Glaser, B., 2015. Acceleration of biochar surface oxidation during composting? Journal of Agriculture and Food Chemistry 63, 3830-3837.

Zhang, R., 1997. Determination of soil sorptivity and hydraulic conductivity from the disk infiltrometer. Soil Science Society of America Journal 61, 1024-1030. 